\title{
Nominal and real stochastic convergence of transition economies
}

\author{
Ali M. Kutan ${ }^{\mathrm{a}, \mathrm{b}, *}$ and Taner M. Yigit ${ }^{\mathrm{c}}$ \\ a Economics and Finance Department, School of Business, Southern Illinois University, \\ Edwardsville, IL 62026-1102, USA \\ ${ }^{\mathrm{b}}$ Center for European Integration Studies (ZEI), Bonn, Germany \\ ${ }^{\mathrm{c}}$ Bilkent University, Bilkent, 06800 Ankara, Turkey \\ Received 8 August 2002; revised 9 September 2003
}

Kutan, Ali M., and Yigit, Taner M.-Nominal and real stochastic convergence of transition economies

To investigate the sensitivity of real and nominal economic convergence of transition economies to model specification and restrictions, we extend the work of Kočenda [J. Compar. Econ. 29 (2001) 1] by considering a more stable, post-1993 period and by adopting a more recent panel estimation approach. This new technique involves less restrictive assumptions than previous panel unit root techniques by allowing heterogeneity in convergence rates. Our results show less nominal and real economic convergence than those of Kočenda. Journal of Comparative Economics 32 (1) (2004) 23-36. Economics and Finance Department, School of Business, Southern Illinois University, Edwardsville, IL 62026-1102, USA; Center for European Integration Studies (ZEI), Bonn, Germany; Bilkent University, Bilkent, 06800 Ankara, Turkey.

(C) 2003 Association for Comparative Economic Studies. Published by Elsevier Inc. All rights reserved.

JEL classification: O570; C330; F150

\section{Introduction}

Since the early 1990s, the transition economies of Central and Eastern Europe, the Baltic States, and the former Soviet Union have introduced a series of fundamental economic reforms, allowing market forces to play a significant role. Although monetary and exchange rate policies varied significantly across countries (Desai, 1998, Kutan and

\footnotetext{
* Corresponding author.

E-mail addresses: akutan@siue.edu (A.M. Kutan), tyigit@ bilkent.edu.tr (T.M. Yigit). 0147-5967/\$ - see front matter @ 2003 Association for Comparative Economic Studies. Published by Elsevier Inc. All rights reserved. doi:10.1016/j.jce.2003.09.008
} 
Brada, 2000), significant progress was made in reducing the initial inflationary pressures due to monetary overhang. More recently, these countries have begun to experience positive real economic growth. As countries display similar economic performance over time, more real and monetary convergence in macroeconomic fundamentals is expected because the impact of initial conditions declines over time (Backé et al., 2003). Three reasons motivate our investigation of degree of convergence in transition economies. First, the absence of economic convergence within a region may lead to social and political instability due to economic performance that varies significantly across countries. Second, the majority of the Central and Eastern European countries are the front-runners for the European Union (EU) membership. Finally, the majority of the countries have signed association agreements with the EU. Evidence of non-convergence would imply that such institutional linkages with the EU do not necessarily promote macroeconomic convergence.

Until recently, the literature has focused on the convergence of transition economies to EU standards, while convergence within groups has been neglected. Brada and Kutan (2001) examine monetary policy convergence between the candidate economies and the EU, proxied by Germany, and find no convergence between base money in Germany and the transition-economy candidates for EU membership. In contrast, the market-economy candidates, Cyprus, Malta and Turkey, show significant convergence with the German money base. Korhonen and Fidrmuc (2001) test whether the candidate countries display significant correlation of their supply and demand shocks with selected EU economies from 1991 to 2000 and find that, except Estonia and Hungary, the candidate economies display low correlation. Richards and Tersman (1996) examine the issue of price-level convergence between the EU and the transition-economy candidates and find large gaps in price levels with the latter countries exhibiting much lower levels than existing EU members. Finally, Estrin et al. (2001) test whether convergence has occurred between the ex-Communist block and the West, using per capita output data from 1970 to 1998, which includes pre- and post-reform periods. These authors find little evidence of convergence to the West, either during the pre-reform period or in the full period. Finally, Backé et al. (2003) find significant differences in comparative price levels between EU countries and most Central and Eastern European EU accession countries.

Kočenda (2001) is a notable exception because he studies the nominal and real convergence of macroeconomic fundamentals in several groups of transition economies. Based on geographical location and key institutional factors, such as the association agreements with the $\mathrm{EU}$, he examines real convergence based on industrial output and monetary convergence using data on producer price index (PPI), consumer price index (CPI), narrow money (M1), and nominal and real interest rates during the period from January 1991 to December 1998. Utilizing a commonly employed panel unit root technique, the author tests for convergence within transition countries grouped according to different institutional and geographical aspects. His results indicate considerable real and monetary convergence; real output displays the greatest degree of convergence across all groups of countries while price levels exhibit the least. The first-round EU candidates show relatively high degrees of convergence. However, as a specific group sharing tight exchange rate regimes and no independent monetary policy, the Baltic States yield the highest degree of convergence. 
The purpose of this paper is twofold. First, we provide additional evidence about real and nominal economic convergence of transition economies by extending Kočenda's study in a more stable post-1993 period to examine the robustness of his findings when the turbulent years of transition are omitted. ${ }^{1}$ Second, we investigate the sensitivity of his convergence results by using a less restrictive panel estimation technique. Kočenda's methodology assumes that countries share a common convergence rate toward long run equilibrium. In this paper, we allow for heterogeneity in these rates to investigate the impact of imposing fewer restrictions on convergence results. Allowing for such disparities in the transition countries' paths to their steady states yields significantly different results and new policy implications. In the next section, we describe our panel methodology and compare it with Kočenda's technique. Section 3 explains our data discuss the convergence results. Section 4 concludes with the policy implications of our findings.

\section{Methodology}

In the past decade, much empirical work on neoclassical growth model uses time series methodology to test for a convergence hypothesis. Based mainly on unit root tests, this literature focuses on capturing the persistence of shocks relative to per capita incomes. ${ }^{2}$ Stochastic convergence applies if per capita income disparities between economies follow a mean-stationary process so that relative per capita income shocks lead to transitory deviations from any tendency toward convergence. Such stationarity would imply that the economies have reached their own steady state. Univariate unit root tests suffer from low statistical power in finite samples, which may lead to failures in rejecting a false nullhypothesis. To address this issue, panel unit root tests that have significantly increased power are used to test for convergence in Quah (1992), Levin and Lin (1993), and Im et al. (2003).

Quah (1992) considers the simple following dynamic model to improve the power of the univariate Dickey-Fuller procedures:

$$
\left(y_{i, t}-\bar{y}_{t}\right)=\rho\left(y_{i, t-1}-\bar{y}_{t-1}\right)+\varepsilon_{i, t},
$$

where $y_{i, t}-\bar{y}_{t}$ is the income disparity from mean output, or from the benchmark economy of $i=1, \ldots, N$ countries at time $t$. He suggests a pooled ordinary-least-squares (OLS) estimation, in which values of $\rho$ less than 1 indicate that disparity from the mean is decreasing with time. Quah shows that his statistic converges weakly to $N(0,1)$ as the number of countries and sample size get large; he uses this technique to find evidence against convergence to US output.

\footnotetext{
${ }^{1}$ Bernard and Durlauf (1996) criticize time series tests of convergence as being unreliable when used for countries that are far away from their steady state.

2 Earlier papers concentrate on the notions of $\beta$ convergence (Barro and Sala-i-Martin, 1992), in which poor countries grow faster than rich ones, and $\sigma$ convergence (Friedman, 1992; Quah, 1993), in which income variance between poor and rich countries is diminishing. Our analysis concentrates on stochastic convergence, which does not require each country to converge to the same steady state.
} 
Levin and Lin (1993) and Levin et al. (2002) provide a more general testing framework, denoted LL, by considering the following three models:

$$
\Delta\left(y_{i, t}-\bar{y}_{t}\right)=\rho\left(y_{i, t-1}-\bar{y}_{t-1}\right)+\alpha_{m i} d_{m t}+\varepsilon_{i, t}
$$

for $m=1,2,3$ and where $d_{m t}$ contains deterministic variables, namely, $d_{1 t}=\{\cdot\}$, $d_{2 t}=\{1\}, d_{3 t}=\{1, t\}$. In other words, they improve on Quah's method by including fixed effects and individual time trends for each country. Such a framework allows both different steady states for the variable $y_{i, t}$ and different time trends for each country. After establishing that asymptotics of their statistics converge weakly to $N(0,1)$ under the nullhypothesis, these authors illustrate that the no convergence hypothesis, namely $\rho=0$, can be tested against the alternative hypothesis of income disparities dampening over time, $\rho<0$. Kočenda (2001) utilizes this methodology to demonstrate convergence in transition economies. ${ }^{3}$

Both the Quah and the LL tests, and consequently Kočenda's methodology, assume that $\rho$, and hence the convergence rate $(1-\rho)$, is the same for all countries in each group. This homogeneity assumption requires all countries within each group to share a common average speed of adjustment to steady state equilibria in all variables. Hence, only inference about convergence rate of the whole group can be drawn. Therefore, this approach provides a natural and appealing technique for comparing the behavior of the cross-section of countries over time. However, a different technique should be used for individual countries to allow for differences in their convergence rates. As we demonstrate, this technique generates distinctly different results when applied to the same economic data if heterogeneity within the group members is statistically significant.

Im et al. (2003) relax the assumption of homogeneity in convergence rates because of potential bias in heterogeneous panels. Therefore, their test does not impose identical convergence rates and consequently avoids possible misspecification of the model, which may lead to false inference. Their method, denoted IPS, pools $N$ separate independent Augmented Dickey-Fuller (ADF) regressions:

$$
\Delta\left(y_{i, t}-\bar{y}_{t}\right)=\delta_{i}+\rho_{i}\left(y_{i, t-1}-\bar{y}_{t-1}\right)+\sum_{k=1}^{p} \phi_{i, k} \Delta\left(y_{i, t-k}-\bar{y}_{t-k}\right)+u_{i, t} .
$$

This procedure allows for heterogeneity in $\rho$ by testing the null-hypothesis, $\rho_{i}=0$ for all $I$, against the alternative hypothesis, $\rho_{i}<0$ for at least one $i$. The limiting distribution for their $t$-statistic is given as

$$
\sqrt{N} \frac{\left(\bar{t}_{\mathrm{ADF}}-\mu_{\mathrm{ADF}}\right)}{\sqrt{\sigma_{\mathrm{ADF}}^{2}}} \rightarrow N(0,1),
$$

where the moments $\mu_{\mathrm{ADF}}$ and $\sigma_{\mathrm{ADF}}^{2}$ are obtained from Monte Carlo simulations, and $\bar{t}_{\mathrm{ADF}}$ is the average estimated ADF $t$-statistics from the sample. They perform subsequent Monte Carlo simulations to compare the size and power performance of their method with that of

\footnotetext{
${ }^{3}$ Kočenda extends this methodology by controlling for serial correlation in errors and computing the exact sample critical values for the tests.
} 
LL. Not only does the IPS test have significantly greater power compared to the LL test, especially when the number of countries is small, but it also has better size properties when the choice of the ADF order is misspecified.

LL and IPS techniques both share the common assumption of an identically and independently distributed (i.i.d.) error structure. When this assumption is violated and residuals are contemporaneously correlated, Maddala and Wu (1999) and Strauss and Yigit (2003) show that both techniques will suffer from significant size distortions that do not disappear by simple demeaning. Therefore, for the remaining part of the paper, we make size adjustments by deriving new critical values for both the LL and IPS tests. The simulated values are generated from 3000 iterations using the contemporaneous correlation matrices obtained from the datasets used in the estimations. Critical values corresponding to those estimations that require a trend were generated using a trend. Differences in performance of these two techniques are caused mainly by the imposition of the homogeneity assumption in LL. Despite the appeal of analyzing the behavior of entire group overtime, the assumption of a common convergence rate may lead to false inference due to the misspecification of the model. These disparities will grow as the degree of heterogeneity within the panels gets larger indicating different paths to steady states. This possibility of misspecification in an LL test motivates our re-examination of Kočenda's results by using a new test for convergence among transition economies.

\section{Convergence of transition economies}

Following Kočenda (2001), we test for convergence in seasonally adjusted growth rates in monthly output (industrial production), price (PPI and CPI), narrow money (M1), and nominal and real interest rate spreads series for 5 groups of countries. ${ }^{4}$ The first group is original participants of Central European Free Trade Agreement (CEFTA), namely, the Czech Republic, Hungary, Poland, Slovakia, and Slovenia. The second group is these five CEFTA countries plus Romania. The third group consists of leading accession countries to the EU, namely, the Czech Republic, Estonia, Hungary, Poland, and Slovenia. The fourth group is made of laggard EU accession countries, namely, Latvia, Romania, the Slovak Republic, Lithuania, and Bulgaria..$^{5}$ The final group is the Baltic countries, namely Estonia, Latvia, and Lithuania. The data are obtained from International Financial Statistics of the IMF.

We concentrate on a more recent and less turbulent period than did Kočenda, namely the beginning of 1993 to the end of 2000. The reason for this change in coverage is that evidence for stochastic convergence, when present, should be stronger with closer proximity to the steady state. The descriptive statistics in Table 1, especially the standard

\footnotetext{
${ }^{4}$ Spread is measured as the difference between lending and deposit rates. Real spread is constructed by subtracting inflation from the nominal spread.

5 Kočenda divides the transition countries into first- and second-group EU candidate countries. Our classification of front-runners and laggards correspond to that of Kočenda, respectively, in terms of country coverage. Although Latvia, Lithuania, and Slovakia are now officially included in the first-round candidate countries, we include them here in the laggards' group for comparison purposes with Kočenda.
} 
Table 1

Means and standard deviations of percentage growth rates, with standard deviations in parentheses and Kočenda values in bold

\begin{tabular}{|c|c|c|c|c|c|c|}
\hline & $\begin{array}{l}\text { Industrial } \\
\text { production }\end{array}$ & PPI & CPI & M1 & $\begin{array}{c}\text { Nominal } \\
\text { spread }\end{array}$ & $\begin{array}{c}\text { Real } \\
\text { spread }\end{array}$ \\
\hline \multirow[t]{4}{*}{ Czech } & 4.96 & 4.08 & 7.29 & 11.93 & 1.83 & 1.00 \\
\hline & (8.6) & $(2.1)$ & $(3.0)$ & (18.29) & $(0.1)$ & $(0.7)$ \\
\hline & 1.97 & 4.54 & 8.42 & 11.35 & 1.81 & -3.04 \\
\hline & (9.77) & (1.95) & (2.33) & (20.68) & $(0.14)$ & (2.04) \\
\hline \multirow[t]{4}{*}{ Slovakia } & 3.61 & 8.80 & 6.12 & 6.40 & 1.55 & 0.74 \\
\hline & $(4.9)$ & $(3.2)$ & $(3.4)$ & $(9.4)$ & $(0.2)$ & $(0.3)$ \\
\hline & -1.67 & 5.96 & 9.90 & 8.52 & 1.56 & -4.15 \\
\hline & $(5.02)$ & (3.41) & (5.38) & (7.54) & $(0.22)$ & (5.27) \\
\hline \multirow[t]{4}{*}{ Poland } & 5.06 & 13.31 & 16.25 & 23.49 & 1.23 & 0.39 \\
\hline & (9.2) & $(7.8)$ & $(7.7)$ & (10.3) & $(0.2)$ & $(0.3)$ \\
\hline & -12.34 & 18.94 & 22.53 & 25.64 & 1.16 & -19.38 \\
\hline & (8.82) & $(\mathbf{8 . 0 3})$ & (9.94) & (7.60) & $(0.17)$ & (12.35) \\
\hline \multirow[t]{4}{*}{ Hungary } & 9.59 & 14.40 & 16.05 & 14.38 & 1.29 & 0.33 \\
\hline & $(7.3)$ & $(6.7)$ & $(5.6)$ & $(6.1)$ & $(0.1)$ & $(0.1)$ \\
\hline & -4.69 & 9.54 & 18.56 & 13.99 & 1.31 & -13.39 \\
\hline & (21.51) & (17.82) & (4.47) & (8.08) & $(0.17)$ & (3.61) \\
\hline \multirow[t]{4}{*}{ Slovenia } & 2.96 & 8.02 & 10.42 & 26.21 & 1.54 & 0.82 \\
\hline & $(4.2)$ & $(4.6)$ & $(3.7)$ & (15.6) & $(0.1)$ & $(0.2)$ \\
\hline & -9.34 & 11.80 & 13.99 & 29.65 & 1.51 & -5.16 \\
\hline & (9.99) & (9.12) & (10.20) & (16.83) & $(0.18)$ & (6.53) \\
\hline \multirow[t]{4}{*}{ Estonia } & 4.25 & 11.86 & 11.86 & 28.57 & 2.25 & 1.04 \\
\hline & (15.7) & (10.8) & (10.8) & $(23.4)$ & $(0.4)$ & $(0.8)$ \\
\hline & -5.58 & 12.35 & 28.01 & 30.94 & 2.22 & -16.32 \\
\hline & (15.44) & (7.70) & (28.21) & (28.24) & $(0.46)$ & (19.02) \\
\hline \multirow[t]{4}{*}{ Latvia } & 7.21 & 12.45 & 4.50 & 16.21 & 2.44 & 2.22 \\
\hline & $(20.0)$ & (10.4) & $(6.1)$ & (13.8) & $(0.5)$ & $(1.2)$ \\
\hline & -7.00 & 39.53 & 26.00 & 18.44 & 2.43 & -0.70 \\
\hline & (16.47) & (102.27) & (34.22) & (14.66) & $(0.54)$ & (10.42) \\
\hline \multirow[t]{4}{*}{ Lithuania } & -2.06 & 31.11 & 34.68 & 23.09 & 1.69 & 4.71 \\
\hline & $(22.4)$ & $(47.3)$ & (59.9) & $(23.5)$ & $(0.5)$ & (13.6) \\
\hline & -18.42 & 42.78 & 38.49 & 29.93 & 1.63 & -31.74 \\
\hline & (35.83) & (66.98) & $(50.12)$ & (21.90) & $(0.49)$ & $(52.16)$ \\
\hline \multirow[t]{4}{*}{ Romania } & -0.90 & 54.16 & 52.94 & 43.32 & NA & NA \\
\hline & (11.6) & (33.8) & (32.9) & (13.8) & NA & NA \\
\hline & -79.60 & 70.98 & 73.50 & 48.90 & NA & NA \\
\hline & (45.70) & (37.37) & (39.76) & (19.50) & NA & NA \\
\hline \multirow[t]{4}{*}{ Bulgaria } & 3.09 & 67.20 & 71.02 & 63.52 & 2.51 & -1.04 \\
\hline & $(12.2)$ & (84.3) & (105.8) & $(68.2)$ & $(1.2)$ & (17.8) \\
\hline & NA & NA & 73.74 & 78.05 & 2.10 & -56.93 \\
\hline & NA & NA & (77.31) & (71.84) & (1.19) & (70.87) \\
\hline
\end{tabular}

Note: NA means data not available.

deviations, illustrate this point as they are consistently below the values in Kočenda's tables. In our paper, we measure real convergence using real industrial production variable, while our analysis of nominal convergence starts with the tests of monetary policy convergence. Although we use both narrow money and interest rate spreads to measure monetary convergence, we think that interest rate spreads are better measures of monetary 
policy. Changes in nominal lending and interest rates affect demand and time deposits directly and thus affect the composition of M1. Hence, changes in M1 are more a policy reflection of outcomes than of the actual implementation of policy. Therefore, we rely more on interest rate results in our conclusions. Additional tests for nominal convergence using the CPI and the PPI reflect not only monetary policy outcomes, but also the trade linkages between the countries.

Initially, we conduct LL tests on the same sets of countries and variables in Kočenda to examine the sensitivity of his results to using an updated dataset. For these tests and subsequent IPS panel unit root tests, the data are demeaned to remove the common time component, which might cause false inference due to cross-correlation within the panels. New critical values are derived for both LL and IPS tests to correct for the size distortions

Table 2

Critical values for the replication of Kočenda type estimations

\begin{tabular}{|c|c|c|c|c|c|c|c|}
\hline & & $\begin{array}{l}\text { Industrial } \\
\text { production }\end{array}$ & PPI & CPI & M1 & $\begin{array}{c}\text { Nominal } \\
\text { spread }\end{array}$ & $\begin{array}{c}\text { Real } \\
\text { spread }\end{array}$ \\
\hline \multirow[t]{3}{*}{ CEFTA-5 } & $1 \%$ & -2.75 & -3.09 & -3.16 & -2.81 & -2.91 & -2.82 \\
\hline & $5 \%$ & -2.02 & -2.33 & -2.48 & -2.14 & -2.16 & -2.04 \\
\hline & $10 \%$ & -1.62 & -1.93 & -2.04 & -1.75 & -1.80 & -1.66 \\
\hline \multirow[t]{3}{*}{ CEFTA-6 } & $1 \%$ & -2.87 & -3.07 & -3.27 & -3.07 & & \\
\hline & $5 \%$ & -2.13 & -2.36 & -2.50 & -2.19 & & \\
\hline & $10 \%$ & -1.73 & -1.92 & -2.08 & -1.83 & & \\
\hline \multirow[t]{3}{*}{ Front-runners } & $1 \%$ & -2.91 & -3.49 & -3.42 & -2.82 & -2.77 & -2.87 \\
\hline & $5 \%$ & -2.14 & -2.66 & -2.68 & -2.11 & -2.18 & -2.13 \\
\hline & $10 \%$ & -1.76 & -2.21 & -2.27 & -1.72 & -1.78 & -1.77 \\
\hline \multirow[t]{3}{*}{ Laggards } & $1 \%$ & -2.89 & -3.28 & -3.02 & -3.00 & & \\
\hline & $5 \%$ & -2.20 & -2.43 & -2.27 & -2.24 & & \\
\hline & $10 \%$ & -1.80 & -2.03 & -1.83 & -1.87 & & \\
\hline \multirow[t]{3}{*}{ Baltics } & $1 \%$ & -2.76 & -2.97 & -3.68 & -2.76 & -2.63 & -2.80 \\
\hline & $5 \%$ & -2.11 & -2.29 & -2.88 & -2.00 & -1.95 & -2.12 \\
\hline & $10 \%$ & -1.72 & -1.94 & -2.42 & -1.67 & -1.59 & -1.76 \\
\hline
\end{tabular}

Table 3

Moments of the IPS $t$-bar statistic (mean value), simulated under the consideration of cross-correlations within groups

\begin{tabular}{lcccccc}
\hline & $\begin{array}{c}\text { Industrial } \\
\text { production }\end{array}$ & PPI & CPI & M1 & $\begin{array}{c}\text { Nominal } \\
\text { spread }\end{array}$ & $\begin{array}{c}\text { Real } \\
\text { spread }\end{array}$ \\
\hline CEFTA-5 & -2.17 & -2.16 & -2.16 & -2.17 & -2.16 & -2.16 \\
& $(0.56)$ & $(0.49)$ & $(0.45)$ & $(0.54)$ & $(0.55)$ & $(0.50)$ \\
CEFTA-6 & -1.52 & -2.17 & -1.51 & -2.17 & & \\
& $(0.68)$ & $(0.53)$ & $(0.61)$ & $(0.52)$ & & -2.16 \\
Front-runners & -1.51 & -2.15 & -2.16 & -2.17 & -2.16 & $(0.53)$ \\
& $(0.63)$ & $(0.40)$ & $(0.35)$ & $(0.53)$ & $(0.52)$ & \\
Laggards & -2.03 & -1.44 & -2.16 & -1.51 & & \\
& $(0.67)$ & $(0.60)$ & $(0.52)$ & $(0.62)$ & & -2.03 \\
Baltics & -1.51 & -1.50 & -2.15 & -1.51 & -2.16 & $(0.69)$ \\
& $(0.63)$ & $(0.45)$ & $(0.11)$ & $(0.64)$ & $(0.58)$ & $(0.6)$ \\
\hline
\end{tabular}

Note. Variance in parentheses. 
Table 4

LL convergence coefficients for all groups, with $t$-statistics in parentheses

\begin{tabular}{|c|c|c|c|c|c|c|}
\hline Group & $\begin{array}{l}\text { Industrial } \\
\text { production }\end{array}$ & PPI & CPI & M1 & $\begin{array}{c}\text { Nominal } \\
\text { spread }\end{array}$ & $\begin{array}{c}\text { Real } \\
\text { spread }\end{array}$ \\
\hline \multirow[t]{2}{*}{ CEFTA-5 } & $0.83^{* * *}$ & $0.97^{* * *}$ & $0.98^{* *}$ & $0.96^{* * *}$ & $0.97^{* *}$ & $0.95^{\text {*** }}$ \\
\hline & $(-4.23)$ & $(-3.99)$ & $(-2.91)$ & $(-3.69)$ & $(-2.50)$ & $(-2.93)$ \\
\hline \multirow[t]{2}{*}{ CEFTA-6 } & $0.85^{* * *}$ & $0.95^{\text {*** }}$ & $0.96^{* * *}$ & $0.96^{* * *}$ & & \\
\hline & $(-4.42)$ & $(-7.20)$ & $(-5.01)$ & $(-3.89)$ & & \\
\hline \multirow[t]{2}{*}{ Front-runners } & $0.83^{* * *}$ & $0.97^{\text {*** }}$ & $0.97^{* * * *}$ & $0.95^{* * *}$ & $0.97^{*}$ & $0.95^{* * *}$ \\
\hline & $(-3.71)$ & $(-3.91)$ & $(-4.43)$ & $(-4.05)$ & $(-1.79)$ & $(-3.48)$ \\
\hline \multirow[t]{2}{*}{ Laggards } & $0.80^{* * *}$ & $0.90^{* * * *}$ & $0.97^{* * *}$ & $0.97^{* * *}$ & & \\
\hline & $(-4.05)$ & $(-7.14)$ & $(-3.97)$ & $(-3.44)$ & & \\
\hline \multirow[t]{2}{*}{ Baltics } & $0.78^{* * * *}$ & $0.93^{\text {*** }}$ & $0.83^{* * *}$ & $0.93^{* * *}$ & $0.82^{* * *}$ & $0.70^{* * *}$ \\
\hline & $(-4.54)$ & $(-4.18)$ & $(-11.15)$ & $(-3.26)$ & $(-4.15)$ & $(-3.05)$ \\
\hline
\end{tabular}

Notes. 1. CEFTA-5 refers to the original CEFTA countries. 2. CEFTA-6 includes Romania. 3. Interest rate results for the CEFTA- 6 and the laggard candidate countries are not reported due to lack of data on Romanian interest rates. 4 . Since the samples are different, we derive our own critical values in Table 2 to determine the significance levels.

* Significant at the $90 \%$ level.

** Idem., $95 \%$.

*** Idem., $99 \%$

caused by residual cross correlation; we record these in Tables 2 and 3. In Table 4, we present the coefficient values and significance levels for the LL tests using the different time periods from that of Kočenda. For this table and the remaining ones, the reported coefficients are one plus the estimates of the autoregressive term $\rho$ or $\rho_{i}$ from Eqs. (2) and (3), and the $t$-statistics below them are for the one-tailed test of $\rho$ equaling to 0 . The results in Table 4 indicate both real and nominal convergence between the countries in each group as found by Kočenda. Hence, moving the window of analysis from 1991 to 1998 to 1993 to 2000 does not lead to significant differences in evidence supporting convergence. The key issue is the sensitivity of the results to using a different panel approach that imposes a less restrictive assumption about convergence rates.

Application of IPS tests on the same sets of variables shows that the strong evidence for convergence found in almost all series in Kočenda is not robust to allowing for heterogeneity in convergence rates. Furthermore, average convergence rates of groups from LL estimations are lower than the convergence rates found using the IPS technique. ${ }^{6}$ When comparing the results in these tables with those of Kočenda's in Table 4, one should keep in mind that the IPS methodology tests for convergence within a group by averaging the $t$-statistics of the individual countries in the group while LL tests used by Kočenda employ the $t$-statistic for the entire group. We report the individual country statistics as well to indicate potential non-convergent countries.

For the original CEFTA countries, Table 5 indicates real convergence as found also by Kočenda, who suggests that this result is likely to be driven by the institutional trade

\footnotetext{
${ }^{6}$ Using a different methodology, Lee et al. (1997) show that not allowing for heterogeneity in convergence rates biases them downward.
} 
Table 5

IPS convergence coefficients for original CEFTA countries, with individual $t$-statistics in parentheses

\begin{tabular}{lcccccc}
\hline & $\begin{array}{c}\text { Industrial } \\
\text { production }\end{array}$ & PPI & CPI & M1 & $\begin{array}{c}\text { Nominal } \\
\text { spread }\end{array}$ & $\begin{array}{c}\text { Real } \\
\text { spread }\end{array}$ \\
\hline Czech & 0.50 & 0.93 & 0.95 & 0.92 & 0.79 & 0.95 \\
& $(-3.49)$ & $(-1.77)$ & $(-1.38)$ & $(-2.36)$ & $(-2.22)$ & $(-0.73)$ \\
Hungary & 0.32 & 0.95 & 0.94 & 0.96 & 0.86 & 0.68 \\
& $(-3.72)$ & $(-2.52)$ & $(-2.76)$ & $(-1.2)$ & $(-2.49)$ & $(-2.91)$ \\
Poland & 0.83 & 0.89 & 0.94 & 0.93 & 0.83 & 0.87 \\
Slovakia & $(-1.96)$ & $(-2.53)$ & $(-1.07)$ & $(-1.17)$ & $(-2.04)$ & $(-2.20)$ \\
Slovenia & 0.79 & 0.84 & 0.90 & 0.94 & 0.66 & 0.71 \\
& $(-1.55)$ & $(-1.91)$ & $(-2.19)$ & $(-1.33)$ & $(-2.57)$ & $(-3.31)$ \\
$t$-bar & 0.63 & 0.91 & 0.90 & 0.89 & 0.31 & 0.75 \\
Standardized $t$-bar & $(-2.91)$ & $(-2.14)$ & $(-2.73)$ & $(-2.42)$ & $(-4.14)$ & $(-3.18)$ \\
\hline
\end{tabular}

Notes. 1. All series include 96 observations and a time trend. 2. The averages of $t$-statistics are compared to simulated values of mean and variance in Table 3. 3. Significance values for individual $\rho_{i}$ are not reported because the IPS (2003) methodology only derives the probability distribution and computes the critical values of their average, $t$-bar.

* Significant at the $90 \%$ level.

** Idem., $95 \%$.

Table 6

IPS convergence coefficients for enlarged CEFTA countries, with individual $t$-statistics in parenthesis

\begin{tabular}{|c|c|c|c|c|}
\hline & $\begin{array}{l}\text { Industrial } \\
\text { production }\end{array}$ & PPI & CPI & M1 \\
\hline Czech & $\begin{array}{c}0.64 \\
(-3.02)\end{array}$ & $\begin{array}{c}0.89 \\
(-3.38)\end{array}$ & $\begin{array}{c}0.91 \\
(-2.71)\end{array}$ & $\begin{array}{r}0.79 \\
(-3.91)\end{array}$ \\
\hline Hungary & $\begin{array}{c}0.62 \\
(-2.64)\end{array}$ & $\begin{array}{c}0.88 \\
(-5.14)\end{array}$ & $\begin{array}{c}0.95 \\
(-2.67)\end{array}$ & $\begin{array}{r}0.97 \\
(-0.82)\end{array}$ \\
\hline Poland & $\begin{array}{c}0.72 \\
(-2.62)\end{array}$ & $\begin{array}{c}0.90 \\
(-2.62)\end{array}$ & $\begin{array}{c}0.96 \\
(-1.74)\end{array}$ & $\begin{array}{r}0.92 \\
(-1.43)\end{array}$ \\
\hline Romania & $\begin{array}{c}0.82 \\
(-2.14)\end{array}$ & $\begin{array}{c}0.86 \\
(-4.14)\end{array}$ & $\begin{array}{c}0.94 \\
(-2.42)\end{array}$ & $\begin{array}{c}0.82 \\
(-2.49)\end{array}$ \\
\hline Slovakia & $\begin{array}{c}0.84 \\
(-1.14)\end{array}$ & $\begin{array}{c}0.81 \\
(-3.62)\end{array}$ & $\begin{array}{c}0.96 \\
(-1.67)\end{array}$ & $\begin{array}{r}0.92 \\
(-1.38)\end{array}$ \\
\hline Slovenia & $\begin{array}{c}0.74 \\
(-2.49)\end{array}$ & $\begin{array}{c}0.86 \\
(-3.28)\end{array}$ & $\begin{array}{r}0.938 \\
(-2.01)\end{array}$ & $\begin{array}{r}0.87 \\
(-2.45)\end{array}$ \\
\hline$t$-bar & $-2.34^{* * *}$ & $-3.69^{* * *}$ & $-2.20^{* *}$ & -2.08 \\
\hline Standardized $t$-bar & $-2.40^{* * *}$ & $-5.06^{* * *}$ & $-2.13^{* *}$ & 0.34 \\
\hline
\end{tabular}

Notes. 1. Only PPI and M1 growth series have a time trend. 2. Interest rate spread results are not reported due to lack of data on Romanian interest rates. 3. Significance values for individual $\rho_{i}$ are not reported because the IPS (2003) methodology only derives the probability distribution and computes the critical values of their average, $t$-bar.

** Significant at the $95 \%$ level.

*** Idem., $99 \%$.

linkages between countries in CEFTA. However, no evidence of nominal convergence is found. Hence, we conclude that the countries have experienced uncommon money and price shocks that were driven by different types of supply and demand shocks. Dibooglu and Kutan (2001) report similar results for real exchange rates in transition economies. 
Table 7

IPS convergence coefficients for the leading EU candidate countries, with individual $t$-statistics in parentheses

\begin{tabular}{lcccccc}
\hline & $\begin{array}{c}\text { Industrial } \\
\text { production }\end{array}$ & PPI & CPI & M1 & $\begin{array}{c}\text { Nominal } \\
\text { spread }\end{array}$ & $\begin{array}{c}\text { Real } \\
\text { spread }\end{array}$ \\
\hline Czech & 0.77 & 0.94 & 0.96 & 0.94 & 0.60 & 0.92 \\
Estonia & $(-1.72)$ & $(-1.63)$ & $(-1.05)$ & $(-2.03)$ & $(-4.76)$ & $(-1.17)$ \\
& 0.85 & 0.92 & 0.90 & 0.94 & 0.51 & 0.63 \\
Hungary & $(-1.60)$ & $(-1.63)$ & $(-2.85)$ & $(-2.28)$ & $(-6.01)$ & $(-3.24)$ \\
& 0.73 & 0.95 & 0.94 & 0.93 & 0.75 & 0.75 \\
Poland & $(-2.02)$ & $(-2.46)$ & $(-2.88)$ & $(-1.68)$ & $(-3.71)$ & $(-2.75)$ \\
& 0.73 & 0.91 & 0.87 & 0.90 & 0.71 & 0.63 \\
Slovenia & $(-2.50)$ & $(-2.24)$ & $(-2.40)$ & $(-2.11)$ & $(-4.12)$ & $(-3.32)$ \\
& 0.67 & 0.89 & 0.89 & 0.88 & 0.55 & 0.53 \\
$t$-bar & $(-2.66)$ & $(-2.92)$ & $(-2.55)$ & $(-2.44)$ & $(-5.68)$ & $(-3.96)$ \\
Standardized $t$-bar & $-2.10^{* *}$ & -2.17 & -2.34 & -2.10 & $-4.86^{* * *}$ & $-2.88^{* *}$ \\
\hline
\end{tabular}

Notes. 1. All growth series, except industrial production, have a time trend. 2. Significance values for individual $\rho_{i}$ are not reported because the IPS (2003) methodology only derives the probability distribution and computes the critical values of their average, $t$-bar.

** Significant at the $95 \%$ level.

*** Idem., 99\%.

Romania is added to the original five CEFTA countries in Table 6. We observe continued real convergence and the emergence of price-level convergence for both CPI and PPI, but we continue to find no evidence of monetary policy (M1) convergence. This dramatic change in results when one country is added raises concern about panel unit root tests in testing for convergence in the presence of outliers.

Table 7 reports the results for the leading EU accession candidate countries, denoted as front-runners. These consist of the CEFTA-5 without Slovakia but Estonia added. We find moderate evidence for real convergence and significant monetary policy convergence, using interest rate spreads. Price level convergence and convergence in money supply growth are not found; this may be due to different inflationary or supply shocks across countries.

Table 8 reports the findings for the laggard EU accession candidate countries. Unlike for the front-runners, no evidence of real convergence is found. However, there is a significant degree of price-level convergence for both CPI and PPI and money supply (M1) convergence, which is consistent with the results in Kočenda. ${ }^{7}$ These results suggest that the laggards have made significant progress in price convergence due to implementation of significant disinflation policies after 1993. This leads us to believe that the gap between the leading and laggard candidate countries is not as large as expected. ${ }^{8}$ A recent decision by the European Council (EC) on the enlargement issue supports our findings. In the EC

\footnotetext{
7 Kočenda does not report results for real convergence for the laggard candidates due to lack of data.

8 However, the result does not mean that the leading group candidate countries have made no progress. Rather, it suggests that the laggards have made harmonious progress toward their long run equilibrium relative to the leading countries after 1993
} 
Table 8

IPS convergence coefficients for the laggard candidate countries, with individual $t$-statistics in parentheses

\begin{tabular}{lcccc}
\hline & Industrial production & PPI & CPI & M1 \\
\hline Bulgaria & 0.25 & 0.93 & 0.93 & 0.94 \\
Latvia & $(-2.14)$ & $(-3.35)$ & $(-2.11)$ & $(-2.61)$ \\
Lithuania & 0.83 & 0.94 & 0.94 & 0.92 \\
& $(-1.04)$ & $(-3.71)$ & $(-2.21)$ & $(-1.73)$ \\
Romania & 0.84 & 0.94 & $(-1.66)$ & 0.91 \\
& $(-0.67)$ & $(-2.90)$ & 0.71 & 0.92 \\
Slovakia & 0.44 & 0.45 & $(-9.61)$ & $(-1.95)$ \\
& $(-1.73)$ & 0.94 & $(-2.14)$ & $(-2.93$ \\
$t$-bar & 0.28 & $(-3.48)$ & $-3.54^{* * *}$ & $-2.21^{* *}$ \\
Standardized $t$-bar & $(-2.49)$ & $-3.72^{* * *}$ & $-4.24^{* * *}$ & $-1.96^{* *}$ \\
\hline
\end{tabular}

Notes. 1. Only industrial production and CPI growth series have a time trend. 2. Significance values for individual $\rho_{i}$ are not reported because the IPS (2003) methodology only derives the probability distribution and computes the critical values of their average, $t$-bar.

** Significant at the $95 \%$ level.

*** Idem., 99\%.

Table 9

IPS results for Baltic States (coefficients and individual $t$-statistics)

\begin{tabular}{lcccccc}
\hline & $\begin{array}{c}\text { Industrial } \\
\text { production }\end{array}$ & PPI & CPI & M1 & $\begin{array}{c}\text { Nominal } \\
\text { spread }\end{array}$ & $\begin{array}{c}\text { Real } \\
\text { spread }\end{array}$ \\
\hline Estonia & 0.85 & 0.90 & 0.765 & 0.94 & 0.56 & 0.46 \\
Latvia & $(-2.13)$ & $(-2.29)$ & $(-5.22)$ & $(-2.16)$ & $(-2.64)$ & $(-5.32)$ \\
& 0.64 & 0.91 & 0.70 & 0.90 & 0.43 & 0.48 \\
Lithuania & $(-3.69)$ & $(-2.45)$ & $(-8.03)$ & $(-2.03)$ & $(-3.56)$ & $(-5.02)$ \\
& 0.85 & 0.94 & 0.68 & 0.90 & 0.42 & 0.42 \\
$t$-bar & $(-2.51)$ & $(-1.95)$ & $(-10.18)$ & $(-1.81)$ & $(-3.69)$ & $(-5.32)$ \\
Standardized $t$-bar & $-2.78^{* * * *}$ & $-2.23^{* *}$ & $-7.81^{* * *}$ & -2.00 & $-3.29^{* * *}$ & $-5.22^{* * *}$ \\
\hline
\end{tabular}

Notes. 1. Only CPI growth and spread series have a time trend. 2. Significance values for individual $\rho_{i}$ are not reported because the IPS (2003) methodology only derives the probability distribution and computes the critical values of their average, $t$-bar.

** Significant at the $95 \%$ level.

*** Idem., $99 \%$.

meeting in Copenhagen in December 2002, it was decided that, along with the frontrunners, Slovakia, Latvia and Lithuania would also join the EU on May 1, 2004. In relation to other laggard countries, i.e., Bulgaria and Romania, the EU expects that these countries will become members in 2007. Finally, Table 9 indicates that the Baltic countries converge in almost all macroeconomic series, except money supply growth. The lack of convergence in M1 is likely due to the currency board regimes adopted by these countries during our sample period.

In summary, our results suggest that significant monetary policy convergence, as measured by interest rate spreads, has been achieved in the transition economies. We also 
Table 10

Comparison of results: is there stochastic convergence?

\begin{tabular}{|c|c|c|c|c|c|c|}
\hline \multirow[t]{2}{*}{ Group } & \multicolumn{2}{|c|}{ Industrial production } & \multicolumn{2}{|c|}{ PPI } & \multicolumn{2}{|c|}{ CPI } \\
\hline & Kočenda & Ours & Kočenda & Ours & Kočenda & Ours \\
\hline CEFTA-5 & Yes & Yes & Yes & No & Yes & No \\
\hline CEFTA-6 & Yes & Yes & Yes & Yes & Yes & Yes \\
\hline Front runners & Yes & Yes & Yes & No & Yes & No \\
\hline Laggards & N/A & No & N/A & Yes & Yes & Yes \\
\hline \multirow[t]{3}{*}{ Baltics } & Yes & Yes & Yes & Yes & Yes & Yes \\
\hline & \multicolumn{2}{|c|}{ M1 } & \multicolumn{2}{|c|}{ Nominal spread } & \multicolumn{2}{|c|}{ Real spread } \\
\hline & Kočenda & Ours & Kočenda & Ours & Kočenda & Ours \\
\hline CEFTA-5 & Yes & Yes & Yes & Weak & Yes & No \\
\hline CEFTA-6 & Yes & No & & & & \\
\hline Front runners & Yes & No & Weak & Yes & Yes & Yes \\
\hline Laggards & Yes & Yes & & & & \\
\hline Baltics & Yes & No & Yes & Yes & Yes & Yes \\
\hline
\end{tabular}

Notes. 1. N/A indicates that no results are included in Kočenda due to lack of data. 2. 'Weak' indicates evidence of convergence at the $90 \%$ significance level.

find evidence of real convergence in the original CEFTA group, the leading EU accession candidates, and the Baltic countries. Price level convergence is more evident in the Baltic countries and the laggard EU candidate countries. This latter finding is due primarily to our post-1993 sample period because the leading EU candidates and the original five CEFTA countries achieved significant price-level convergence in the early 1990s. The least convergence is observed in money supply (M1) growth. Table 10 presents the differences between our results and those of Kočenda. The entries in bold indicate different inferences regarding convergence. The key difference is that our evidence indicates less convergence in the price indexes and M1. Nominal spread results are also sensitive to the methodology used. We find stronger convergence in nominal spreads for the Baltic countries and weaker convergence for the CEFTA-5 members. Our results also show that panel tests are sensitive to outliers in data.

\section{Policy implications and conclusions}

We test for real and monetary stochastic convergence in transition economies, using macroeconomic data from January 1993 to December 2000. Using a different sample period but employing the same method used by Kočenda, we find no qualitatively different inferences about convergence. However, employing a less restricted panel test that does not impose the assumption of homogeneity in convergence rates, we find less degree of monetary convergence, measured by CPI, PPI, and M1 growth, and real interest spread. Our results suggest that inferences about convergence among transition economies may be more sensitive to restrictions placed on the panel technique employed than to the data period used.

These findings have important policy implications. First, the lack of monetary and price convergence for the leading EU accession candidate countries indicates that these 
countries pursue different macroeconomic objectives with respect to inflation. Hence, this lack of nominal convergence may delay their entry into the European Monetary Union (EMU). Second, we find significant real convergence within all transition countries, with the exception of the laggard EU accession countries. We use industrial production, which may capture supply as well as demand shocks, to measure real convergence. Hence, our findings indicate that the laggard EU candidate countries have experienced different supply and demand shocks that display no convergence with shocks in other countries within the group. As an important policy implication, the laggard candidate countries must retain some degree of policy autonomy to deal with such shocks, the magnitude and timing of which may differ significantly from the shocks affecting other countries in that group. With regard to exchange rate policy, more flexible exchange rate policies are recommended for these countries.

\section{Acknowledgments}

We thank three anonymous referees, Josef Brada, Karel Janda, Muhammad Islam, Evžen Kočenda, Elmar Koch, Jack Strauss, Petr Zemcik, and the participants of BOFIT workshop (2003) on Transition Economics for their useful comments and suggestions on earlier versions of this paper. We also thank John and Hélène Bonin, the Editors, for their support and suggestions. The usual disclaimer applies.

\section{References}

Backé, Peter, Fidrmuc, Jarko, Reininger, Thomas, Schardax, Franz, 2003. Price dynamics in Central and Eastern European EU accession countries. Emerging Markets Finance and Trade 39, 42-78.

Barro, Robert J., Sala-i-Martin, X., 1992. Convergence. Journal of Political Economy 100, 223-251.

Bernard, Andrew B., Durlauf, Steven N., 1996. Interpreting tests of the convergence hypothesis. Journal of Econometrics 71, 161-173.

Brada, Josef C., Kutan, Ali M., 2001. The convergence of monetary policy between candidate countries and the European Union. Economic Systems 25, 215-231.

Desai, Padma, 1998. Macroeconomic fragility and exchange rate vulnerability: a cautionary record of transition economies. Journal of Comparative Economics 26, 621-641.

Dibooglu, Selahattin, Kutan, Ali M., 2001. Sources of real exchange rate fluctuations in transition economies: the case of Poland and Hungary. Journal of Comparative Economics 29, 257-275.

Estrin, Saul, Urga, Giovanni, Lazarova, Stepana, 2001. Testing for ongoing convergence in transition economies 1970 to 1998. Journal of Comparative Economics 29, 677-681.

Friedman, Milton, 1992. Do old fallacies ever die? Journal of Economic Literature 30, 2129-2132.

Im, Kyung S., Pesaran, M. Hashem, Shin, Yongcheol, 2003. Testing for unit roots in heterogeneous panels. Journal of Econometrics 115, 53-74.

Kočenda, Evžen, 2001. Macroeconomic convergence in transition countries. Journal of Comparative Economics 29, 1-23.

Korhonen, Iikka, Fidrmuc, Jarko, 2001. Similarity of supply and demand shocks between the Euro area and the accession countries. Focus on Transition 2, 26-42.

Kutan, Ali M., Brada, Josef C., 2000. The evolution of monetary policy in transition economies. The Federal Reserve Bank of St. Louis Review 82 (2), 31-40.

Lee, K., Pesaran, M.H., Smith, R., 1997. Growth and convergence in multi-country empirical stochastic Solow model. Journal of Applied Econometrics 12 (4), 357-392. 
Levin, Andrew, Lin, Chien-Fu, 1993. Unit root tests in panel data: new results. Working paper No. 93-56. San Diego Department of Economics, Univ. of California.

Levin, Andrew, Lin, Chien-Fu, Chu, Chia-Shang J., 2002. Unit root tests in panel data: asymptotic and finitesample properties. Journal of Econometrics 108, 1-24.

Maddala, G.S., Wu, Shaowen, 1999. A comparative study of unit root tests with panel data and a new simple test. Oxford Bulletin of Economics and Statistics, Special Issue 61, 631-652.

Quah, Danny, 1992. International patterns of growth: persistence in cross-country disparities. Unpublished manuscript. London School of Economics.

Quah, Danny, 1993. Galton's fallacy and tests of the convergence hypothesis. Scandinavian Journal of Economics 95, 427-443.

Richards, Anthony J., Tersman, Gunnar H.R., 1996. Growth, nontradables, and price convergence in the Baltics. Journal of Comparative Economics 23, 121-145.

Strauss, Jack, Yigit, Taner M., 2003. Shortfalls of panel unit root testing. Economics Letters. In press. 